\title{
Chinese Migrants in the Construction Business of the Irkutsk Region: \\ Formal and Informal Organization of Work
}

\author{
Andrej A. Voloshin* \\ Irkutsk State University \\ 1 Karl Marx Str., Irkutsk, 664003, Russia
}

Received on 24.07.2018, revised on 23.10.2018, approved on 07.11.2018

The article is devoted to Chinese labour migrants in the construction sector of the Irkutsk region. The main purpose of the article is to show how the recruitment of Chinese workers at the Irkutsk construction sites takes place, who comes there and for what reasons. The article includes detailed consideration of two construction projects. The article focuses on two fundamentally different models. One of the largest construction companies of Irkutsk was chosen as the first object of research, a dynamically developing company that has extensive experience in attracting foreign labour. The task of the second example (case study) is to show the difference of approaches taken when choosing ways of recruiting workers. The material for the study was a series of author's interviews, personal observations supplemented by materials from the Internet.

Keywords: labour migration, China, recruitment, Chinese migrants, economy, Irkutsk region.

Research area: domestic history.

Citation: Voloshin, A.A. (2018). Chinese migrants in the construction business of the Irkutsk region: formal and informal organization of work. J. Sib. Fed. Univ. Humanit. soc. sci., 11(11), 1805-1815. DOI: 10.17516/1997-1370-0341.

The most important characteristic of the current stage of Russia's economic and social development is the massive use of foreign labour force. If at the beginning of the 2000's, according to experts, the average annual number of labour migrants was about 3 million, now the figure has increased at least twice. These are very rough estimates due to the imperfection of accounting and statistics, as well as the mass presence of undocumented migrants.

(c) Siberian Federal University. All rights reserved

* Corresponding author E-mail address: voloha94@yandex.ru

This work is licensed under a Creative Commons Attribution-NonCommercial 4.0 International License (CC BY-NC 4.0). 
In order to have a real understanding of the impact of this factor on the labour market, on socio-economic relations in general, it is necessary not only to know the quantitative parameters of the phenomenon or a sectoral structure, intensity and direction of cross-border labour migration flows, but also to identify hiring mechanisms and practices, and management of foreign labour. For many years, the Authoritative International Labour Organization (ILO) has focused its attention on this most important issue not only for Russia. According to the ILO, the international practice of hiring workers covers a variety of activities: this includes hiring by employers and their representatives; various operations carried out by public and private recruitment services; search and attraction of workers in one country on behalf of an employer in another country or a situation where a recruitment agency from one country takes the responsibility to employ migrants in another country (On the legal status...).

A situation in the construction industry is of particular importance in this context. Following the trade and service sector, it is the main consumer of the labour of foreign migrants. The degree of dependence of the industry on this factor is enormous - no one has conducted relevant research; more or less reasoned expert assessments, both in the country as a whole and in individual regions, are extremely rare or even absent, but even the most superficial view of the problem shows that if the industry suddenly loses all the guest workers, it will experience deep crises, if not collapse.

In addition, the construction industry has accumulated a large and diverse experience in working with foreign labour, both legal, formalized and illegal, not documented. Both labour of workers who do not have construction professions and of skilled builders is widely used here. They are the workers from the main migration donors for Russia - China and the countries of Central Asia. And again, comparative studies have not been conducted, but the most initial observations show that they differ in both the level of qualification and the conditions and mechanisms for their employment and use. Also the fact that there is a visa regime with China, and there is no visa regime with the donor countries of Central Asia is of great importance.

As a result, a wide variety of practices of hiring foreign workers and mechanisms for using their labour, both legal and illegal, have been developed in the construction business of Russia. And the first steps have been made to study them. Here it is worth recalling the study that was conducted in 2006 with the assistance of the International Labour Office. It was devoted to the problem of the social status of workers from Tajikistan in the construction industry in Moscow and the Moscow region. The authors of the report consider in detail the nature of labour migration from Tajikistan, including 
focusing on the problem of the relationship between an employee and an employer at the stage of employment (The social status of workers..., 2006). Another study that also analyses the problem of hiring foreign workers in the construction business is the article by Elena Skripnik, "North Korean Labour Slavery" in Russia: Socio-Economic Factors" (Diatlov, 2012).

Such traditional forms of recruiting as ties of fellow countrymen, diaspora networks or outsourcing offices have already been mentioned. Now they are gradually pushed aside by the practices in which employers (usually large construction firms) send direct offers that are aimed at representatives from countries near and far abroad. There are a number of structures that are actively involved in the recruitment of workers or have direct or indirect influence on this process. These are the law enforcement agencies, local governments, criminal structures, special services and diaspora public organizations.

However, the vastness of this research field, the huge variety of accumulated and used practices, makes us continue to study the problem. One of the areas of the research may be the description and analysis of individual cases, examples - in order to supplement the picture that is not very clear so far.

The main objective of this study is to show, in two separate examples (cases), how the recruitment of Chinese workers at the Irkutsk construction sites takes place, who comes there and for what reasons, how their order of stay and work is organized. Very different options have been selected - from a large construction organization that has extensive experience in the use of foreign labour and tries to work in the legal field, to a situation of an informal and, in fact, illegal organization of labour. The material for the study was a series of interviews, personal observations supplemented by materials from the Internet.

\section{Case 1: legal option}

One of the largest construction firms in Irkutsk, VostSibStroy, was chosen as the first object of research. It is a dynamically developing enterprise that has a great experience in attracting foreign labour.

In March 2017, a focused interview was conducted with the Chief Specialist for Foreign Labour to collect materials on Chinese migrants. It was supplemented by the included observation, which provided useful information about the daily presence of the Chinese at the construction site.

The company has been cooperating with workers from China since 2004. As the head of the department notes, $90 \%$ of the total number of workers employed in 
construction sites are Chinese. He mentions three main reasons, due to which one of the leaders of the construction industry of the Irkutsk region gives preference to workers from China. First is the quality of work. According to the employers, brigades from China perform the amount of work much faster and more efficiently than our compatriots. The second reason is in the problem of the system of personnel training: "The system of vocational education is almost destroyed, which is why there is a lack of qualified personnel in construction. Especially in such professions where physical labour is required - a bricklayer, a concrete worker..." The third reason is the high interest and motivation of the Chinese, their desire to come to Russia with the goal of making money to feed their families. Chinese builders are very disciplined about work, which cannot be said about the Russians. Here, we should mention the notorious level of responsibility of Russian workers. Very often, they work until the next advance payment or a payday, after which there may be cases of violation of labour discipline. In 2015, the company conducted employment contracts with a group of Russian builders from the Irkutsk region in the amount of 400 people. As a result, only $10 \%$ remained at work - "People unlearned and do not want to work with a salary of 25-30 thousand."

The mechanism for hiring workers is organized as follows. The company undertakes all costs and efforts for the preparation of documents for each employee. Since the company operates in a legal field, the possibility of deception in this case is excluded. The procedure for registration of the brigade of workers at the construction site takes up to 6 months. The search system is fairly transparent. The company cooperates with a foreman from China - an experienced worker who has been working in Russia for several years and speaks Russian at a conversational level. The foreman examines all the design and estimate documentation of the construction object (drawings, calculations, etc.). In turn, he is looking for workers in China given the complexity of the construction site. The standard team includes the following professions: a carpenter, a concrete worker, a bricklayer, a plaster-painter, a fitter. The main requirement for workers is professionalism. The foreman, while in Russia, collects documents for the entire group of workers. The foreman is a Russian-speaking person, an intermediary between an employer and the whole brigade. Often it can be a person with a higher education. Often, the functions of the foreman are not related to construction, he is not a master who performs any work, but only a coordinator and organizer. Unlike a foreign team of builders with a Russian leader, the group of workers with a national team leader is more stable, the probability of conflict situations is lower here. The foreman with the same nationality takes better care of his compatriots and it is usually 
easier to manage a team of builders of this type, thus eliminating problem situations within the team.

Let us consider the procedure for obtaining a work permit for a foreign citizen in the Russian Federation at the time of this study. The first thing to do is to fill out an application with the Irkutsk employment service about the need to attract a foreign specialist. At the same time, it is important to justify why there were no national personnel, otherwise there is no chance to get a permit. The next step is to send an application to the Migration Control Service of the Ministry of Internal Affairs for a work permit. After getting a quota, the organization should prepare other documents and medical certificates; each document is personally notarized. Workers are attracted to a specific object, the permit is valid only within the city. In addition to all bureaucratic difficulties, the organization must pay a state fee for each Chinese in the amount of 10 thousand roubles and go through a number of approvals, ranging from local officials to the migration service management in Moscow. As the head of the department explained, the cost of attracting one Chinese is estimated from 15 to 20 thousand roubles, including the cost of his trip in a second-class car from Zabaykalsk to Irkutsk.

By the way, in April 2017, the first multifunctional migration centre in Eastern Siberia opened in Irkutsk. Its main task is to create transparency in the process of labour migration of foreign citizens, providing them with a range of public services. It also eliminates the presence of intermediary structures. The centre serves over 100 migrants in one day; clients are accepted in the electronic queue mode. According to the experts, the development of multifunctional centres can significantly replenish the budget of the region (A multifunctional migration..., 2017).

People of different age groups from 25 to 45 years old come to work in Russia. The qualification level of migrant builders varies: some of the working citizens from China have a secondary education, but not related to construction. However, those who already received primary experience in construction during adolescence working as welders and carpenters, also come here. It can be argued that modern directions of migration flows from China to Russia are largely related to the geography of the Chinese provinces. Most Chinese migrants come to Russia from the border regions of the north-eastern provinces - Heilongjiang, Jilin, Liaoning and the Inner Mongolia Autonomous Region. These regions are characterized by slow economic development.

The organization is attentive to the issue of legal protection of workers. Like any workers who are officially employed, the Chinese have a full package of social guarantees. In case of violation of labour legislation, they have every right to complain 
to their foreman. According to representatives, during the time of cooperation with the Chinese there was only one case in which workers were faced with violation of rights. Traditionally, the foreman receives plastic cards for each worker, so that they could get a salary. But there was a sad experience, when the foreman decided to deceive the entire brigade taking all the money. Workers had to go on strike, where they voiced their demands. In the event of any abnormal situation in the team, the team leader is obliged to report this to the employer.

\section{Case 2: shady scheme}

The use of foreign labour for construction work in private households is a long and widespread practice. For many years, this category of migrants remained "invisible", since the workers were in an illegal or semi-legal situation. In 2010, the Law "On the Legal Status of Foreign Citizens in the Russian Federation" was amended, which established the legal basis for legalizing the stay of labour migrants with private individuals. The document that gives the official permission to work for hire with an individual has become a patent. Labour migrants who travel to the Irkutsk region are also involved in this sector of the economy. Let us consider in more detail, whether all migrants have a patent (Larin, 2008).

The second object of study was one of such households, where the Chinese citizens work. When trying to collect material for this case, the author had to face a number of problems. Firstly, it is quite difficult to find the owners of private households in order to get at least some information. There are various excuses for this: some of them say they are busy, some simply do not want to help, others ascertained the incompetence in this matter. Secondly, the fact that the Chinese cannot speak Russian. Thirdly, the owners of private households reluctantly allow the Chinese to communicate directly with the researcher, and also do not want the researchers to be present at the construction sites. In their opinion, this kind of information is considered to be confidential and off-limits. The reason for the refusal is obvious here, because many "shady employers" are afraid of facing sanctions from regulatory authorities, "a student ID card is not a guarantee that you are a researcher and the purpose of your visit is purely scientific..." As a result, after numerous unsuccessful attempts, with the help of some good contacts and by prior arrangement, we managed to reach one of the owners of a private household.

In May 2017, I was able to visit such a private construction site in one of the satellite cities of Irkutsk and interview a Chinese group of workers who carried out internal and external work, installed communications. The group consists of workers 
of different specialities: plasterer-painters, tilers-finishers, electricians, plumbers, etc. Also almost all members of the brigade have a good level of adjacent specialities, sets of necessary skills that allow you to safely carry out interchangeability in case of a production need. The group is led by a qualified foreman who speaks Russian relatively well. The foreman also acts as an intermediary, manager and accountant. All responsibility for the work falls on him. The remaining members of the brigade either speak, but often obscuredly, or do not speak Russian at all. The communication with the group of workers was carried out directly through the foreman who agreed to be a translator for the whole group and answer several blocks of questions.

In the first case, we see that the firm is interested in ensuring that its employees are employed in accordance with all the requirements and have work permits. The second example looks diametrically opposite and, here, it is worth talking about risks. The socalled employment in this case is implemented according to shady schemes. As the foreman explained, a group of Chinese citizens come to Russia under the guise of a tourist visit. The term of a tourist visa is 30 days, and at the time of the study, visas for the entire group were overdue. In fact, it is very easy to get visas; it is enough to provide data of a travel agency that invites the Chinese here. But it does not give the right to work. The foreman himself lives and works in Russia for 7 years with short breaks.

The hiring procedure was as follows: the foreman, who lives continuously in Russia, goes to China, where he invites those interested to work in Russia. He does not have a permanent team of workers, but he has many acquaintances that have experience in construction. The employer gives money for transfer and food. There are no documents regulating labour relations. Also there is no package of social guarantees. All of the above actually means that the Chinese have complete legal powerlessness. Salary is not regulated; it all depends on the amount and quality of work. The money is transferred to the foreman who divides salary between the workers. Thus, the risks of non-payment (full or partial) of salary increase. There is nothing more, but the oral agreement between the team and the employer. The employer does not bear any responsibility for the workers. Honesty and decency of the employer and the foreman play the greatest role here.

All members of the brigade, except the foreman, came to Russia for the first time. None of their relatives also have migration experience. During the conversation, it also became clear that the workers had their first thoughts about going to Russia long before the move (3-5 years ago), that is, this decision was not made spontaneously, but was thought through many times. Let us consider the main motives and incentives for 
this. The main reasons for migration were: the need to make a living for a family, the search for funds for education for children, the need to cover private loans, planning investments in the organization and development of their own small business in their homeland. The first place in this list is, of course, occupied by the socio-economic factors, the desire and opportunity to earn money. Often, even a comparatively small or average, by Russian standards, salary of a Chinese builder working in Russia (from $\$ 500$ to $\$ 1,000$ per month) seems to be a very significant and tangible income for residents of poor regions of China.

In addition, the job market in Russia as a whole and in the Baikal region particularly is very diverse and representative. There is even the possibility of further career growth. The youngest member of the brigade ( 25 years old) believes that if working in Russia, he will be able to achieve more: "I have long wanted to come to Russia, for me this is a good chance, I am not old yet. For now I can be a simple worker at the construction site. And if I can show good results in this industry, then I can create my own permanent brigade. I have an experience, but the main thing is to learn Russian. It is very easy to find friends who want to come here. To be honest, I would like to stay here, find a job, I can do a lot of things."

Among other reasons for relocation, the workers identify not only socio-economic, but also geopolitical factors. In particular, migrants note the presence of healthy and good-neighbourly relations between the two states - the Russian Federation and the PRC. As a result, the Chinese consider Russia to be a friend of their country, which forms a trusting attitude. The positive image of Russia is quickly fading away when a migrant has to face a lot of problems in adaptation. Negative perception of the country and the host community is formed at the very beginning of the stay. Firstly, the traditional fraud and extortion by employers and law enforcement agencies. Secondly, according to A.G. Larin, modern mass media have a negative impact on public consciousness, publishing inventions about millions of Chinese illegal immigrants and replicating the opinions of various politicians that are far from objectivity, as well as the statements of high-ranking officials who are interested in creating an image of the new enemy (Consideration of the problems..., 2017). In the host community, this creates grounds for talking about the "Chinese threat." Thirdly, being in Russia, a migrant cannot complain about the conditions of stay and other problems, since for the majority of the population they are alien.

It is clear that there is no talk about a fixed working day at such an object, the average duration of a work shift is $12-16$ hours. Overalls and protective equipment 
(helmets, glasses, gloves) are absent, resulting in an increased risk of injury in the workplace. Due to legal insecurity, the team is forced to almost constantly be at the construction site. Any outing to the city can lead to undesirable meetings with the police, officers of the FMS. There is a chance to become an object of attention for local criminals. Workers note that they have almost no external contacts. The team is isolated and is always within the construction site, except for the foreman. However, even taking into account all the dangers, inconveniences and deprivations, all the same, in the opinion of the workers, work in Russia remains attractive. The only one lawfully residing in the territory of the Russian Federation is the foreman who assimilated and received Russian citizenship a long time ago. At the beginning of his career in Russia, he was engaged in the installation of ventilation and air conditioning systems. Later, he has been learning Russian for 3 years, which undoubtedly helped to develop further. Now the foreman is engaged in construction, searches for workers and arranges them for work.

At the end of the conversation, the migrants indicated the reasons why they chose Irkutsk: geographically close location, climatic conditions similar to China, relatively inexpensive transfer, a large selection of offers on the labour market and a decent level of wages.

\section{Conclusion}

Of course, the two cases do not claim to be a complete analysis of the situation. But they are selected in such a way as to show its certain points. On the one hand, it is a large construction company interested in a stable use of foreign labour for many years and having extensive experience in this area, qualified managers and wellestablished forms of work. The company is committed to the greatest possible legality and transparency; it has the ability to spend significant funds and efforts to complete all the necessary formalities, to pay an officially declared salary with the necessary deductions. Cheap labour of illegal, unregistered migrants is unprofitable and fraught with difficulties with the law enforcement agencies. Large developers are trying to protect themselves from unwanted raids of the FMS and other structures by using and improving the system of selection of qualified personnel, they are interested in the transparency of their chosen practices. Although the format of the legal field also has some loopholes aimed at circumventing problematic aspects.

On the other hand, there is the case representing completely informal relations. It is temporary seasonal work, the absence of any fixed contractual relations, workers 
who entered on tourist visas without the right to work, tax evasion. Complete social insecurity and lack of rights of labour migrants.

However, there is a considerable resemblance in these cases. With all the differences in status and the real situation of workers, they consider labour migration to be beneficial for themselves. Even those unregistered migrants who also have construction specialities and relatively high qualifications. In both cases, the figure of the foreman comes to the fore playing a key role in the relationship between employers and employees. He is not only and not so much the organizer of the work, but an intermediary. It is not by chance that it is a person with a good education, good Russian language proficiency and a relatively long life and work experience in Russia. Most likely, in China he has a certain social capital that allows organizing teams of builders largely based on his own word of honour.

\section{References}

A multifunctional migration centre started its work in Irkutsk: [Electronic resource] (2017). In Main Directorate of the Ministry of Internal Affairs of Russia for the Irkutsk Region: website. Available at: https://38.xn--blaew.xn--plai/news/item/9875586 (accessed 20 May 2018).

Consideration of the problems of management organization in the context of the changing nature of labour migration [Electronic resource] (2017). In $4^{\text {th }}$ report of the International Labour Office. Geneva: International Labour Conference. $106^{\text {th }}$ session. 87 p. Available at: http://www.ilo.org/wcmsp5/groups/public/---ed_norm/---relconf/ documents/meetingdocument/wcms_550536.pdf(Accessed 21 May 2018).

Diatlov, V.I. (2012). Mestnye soobshchestva, mestnaia vlast' i migranty v Sibiri na rubezhakh XIX-XX i XX-XXI vekov: pamiati Anatoliia Viktorovicha Remneva [Local communities, local authorities and migrants in Siberia at the turn of the $19^{\text {th }}-20^{\text {th }}$ and $20^{\text {th }}-21^{\text {st }}$ centuries: in memory of Anatoly Viktorovich Remnev]. Irkutsk State University, Trans-regional institute of social sciences. Irkutsk: Reprint, 463 p.

Larin, A. (2008). Chinese migrants in the eyes of Russians [Electronic resource]. In Demoscope Weekly. (333-334), 19 May - 1 June 2008. Available at: http://demoscope. ru/weekly/2008/0333/tema01.php\#_FNR_(accessed 20 May 2018).

On the legal status of foreign citizens in the Russian Federation [Electronic resource]: Federal Law of July 25, 2002 No. 115-Ф3 (as amended on April 17, 2017). Accessed from the computer-based legal research system "ConsultantPlus" in the local network of the Scientific Library of the Irkutsk State University. 
The social status of workers from Tajikistan in the construction industry in Moscow and the Moscow region [Electronic resource] (2006). In Working report of the International Labour Office. Geneva: Program to promote the Declaration on Fundamental Principles and Rights at Work, February 2006. 107 p. Available at: http://www.ilo.org/wcmsp5/groups/public/---europe/---ro-geneva/---sro-moscow/ documents/publication/wcms_309218.pdf (Accessed 21 May 2018).

\title{
Китайские мигранты в строительном бизнесе Иркутской области: формальная и неформальная организация трудовой деятельности
}

\author{
А.А. Волошин \\ Иркутский государственный университет \\ Россия, 664003, Иркутск, ул. Карла Маркса, 1
}

$\overline{\text { Статья посвящена китайским мигрантам в строительном секторе Иркутской об- }}$ ласти. Основная цель статьи - показать, каким образом осуществляется механизм найма работников для строительных площадок. Кто и по каким причинам приезжает на работу в Иркутск. Включено подробное исследование двух строительных объектов. Рассматриваются две приниипиально разные модели. Первым объектом исследования была выбрана крупнейшая динамично развиваюшаяся строительная компания Иркутска, имеющая большой опыт привлечения иностранной рабочей силь. Задача второго примера (кейса) заключается в том, чтобы показать, как применяются разные подходы при выборе способов найма работников. Материалом для исследования была серия авторских интервью, личных наблюдений, дополненных интернет-материалами.

Ключевые слова: трудовая миграчия, рекрутирование, китайские мигранты, строительная отрасль, Иркутская область.

Научная спещиальность: 07.00.02 - отечественная история. 